\title{
The effect of different solutions and thermocycling on the Vickers hardness of acrylic resin denture teeth
}

\author{
Hatice Özdemir1@i, Zeynep Yeşil Duymuş²® \\ ${ }^{1}$ Atatürk University, Faculty of Dentistry, Department of Prosthodontics, Erzurum, Turkey \\ ${ }^{2}$ Recep Tayyip Erdoğan University, Faculty of Dentistry, Department of Prosthodontics, Rize, Turkey
}

\section{Correspondence:}

\section{Dr. Hatice ÖZDEMiR}

Atatürk University, Faculty of Dentistry, Department of Prosthodontics, Erzurum, Turkey

E-mail:dentist_hatice@hotmail.com

Received: 29 August 2018

Accepted: 16 November 2018

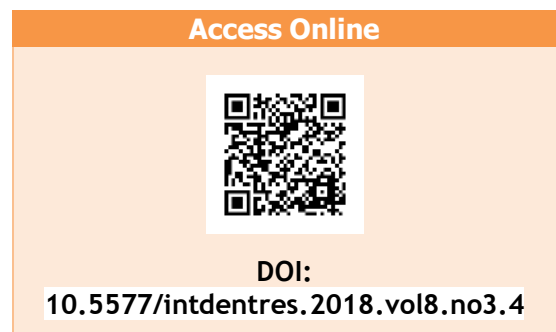

\section{Introduction}

Artificial teeth are often necessary for prosthodontic rehabilitation when natural teeth are lost. Acrylic resins and porcelains have been used for the fabrication of artificial teeth; however, neither teeth. teeth.

\section{Abstract}

Aim: The aim of this study was to evaluate the effect of artificial saliva, disinfectant solution, distilled water, and thermocycling on Vickers hardness of 4 commercial brands of acrylic resin denture teeth.

Methodology: Four different brands of acrylic resin denture teeth (Major Dent, Acry Lux, Acry Rock, Imident Lux) were evaluated. 15 anterior and 15 posterior teeth of each group embedded in autopolymerized acrylic resin. The occlusal surfaces of posterior teeth and the vestibule surfaces of anterior teeth were flattened by using silicon carbide paper. After polishing, microhardness measurements were repeated three times for each teeth. The teeth were submitted to different conditions: (1) storage in distilled water at $37 \pm 2^{\circ} \mathrm{C}$ for 7 days; (2) storage in artificial saliva at $37 \pm 2^{\circ} \mathrm{C}$ for 30 days and (3) storage in $1 \%$ sodium hypochlorite. After, thermal cycling between 5 and $55{ }^{\circ} \mathrm{C}$ for 2500 cycles was made. The microhardness measurements were repeated. Data were analyzed with one-way analysis of variance (ANOVA) and Duncan test $(p<0.05)$.

Results: There were statistically significant differences between initial and final microhardness values of different brands of acrylic resin denture teeth. Anterior teeth showed lower microhardness values than posterior

Conclusions: Storage in different solutions and thermal cycling significantly reduced the Vickers hardness of the acrylic resin denture

Keywords: Solution, hardness, acrylic resin teeth, thermocycling

How to cite this article: Özdemir H, Duymuş ZY. The effect of different solutions and thermocycling on the Vickers hardness of acrylic resin denture teeth. Int Dent Res 2018;8(3):117-22. 
of the effectiveness of chewing, and aesthetic requirements are the main features wanted in the acrylic teeth. Porcelain teeth answer these requirements adequately. But the most important disadvantages of porcelain teeth; brittleness, when used resorbed crest overload transmission, creating sound during chewing, the lack of connection with the denture base material, and the difficulty of matching with the occlusion opposed and is the difficulty in polishing $(3,4)$. The physicals endurances of the acrylic teeth which are used in the full and partial removable prostheses and their aesthetics appeals are the most important physical features. The qualities required in the acrylic teeth varies according to the purpose of the using in anterior or the posterior areas. While aesthetic requirements are important in the anterior teeth used, the structural strength is required to withstand to the forces of chewing teeth used in the posterior areas (5, 6).

Prostheses have been identified as a source of cross-contamination between patient and dental personnel $(7,8)$. Therefore, to reduce the chances of cross-contamination dentures should be disinfected (9). Chemical disinfectant solutions recommended for immersion of dental prostheses include sodium hypochlorite, glutaraldehyde, and chlorine dioxide (10, 11).

Hardness is an important property related to wear resistance (12-17) and it is the most common mechanical property indicator for restorative and artificial teeth materials $(4,18,19)$. Some factors can influence the hardness of resin denture teeth and dental restorative materials, such as mouth environment substances, temperature, and chemical disinfectant solutions $(9,19-23)$.

Historically, Vickers and Knoop hardness tests have been preferred by the majority of investigators for testing hardness of denture teeth or composite resins $(16,18,24)$. Hardness is directly connected with the integrity of a material and its resilience to decay by thermal, chemical or mechanical action (25). In clinical situations, hardness represents dentures' resilience to abrasion over time. A disinfection procedure which decreases dentures' hardness is unacceptable for clinical use because it makes them prone to wear (26).

Thermal cycling is another factor that can alter some properties of the materials used in complete and partial removable dentures (27). This laboratory procedure is an in vitro simulation of thermal alterations that occur inside oral cavity. According to Gale and Darvell (28), tolerable temperatures inside oral cavity can range from 0 to $68{ }^{\circ} \mathrm{C}$. Theoretically, thermal cycling allows the repeated shrinkage and expansion of the material and, consequently, a situation of internal tension $(23,29,30)$ that can influence prostheses durability and bond strength between artificial denture teeth and acrylic resin denture base $(30,31)$

Although studies have evaluated the hardness of artificial teeth and acrylic resin denture base stored in water $(9,16,19)$, few studies have related this property with the storage in saliva that is the fluid in which teeth keep constantly immersed in the oral environment. Moreover, the effect of thermal cycling on the hardness of artificial denture teeth is not frequently reported in literatüre $(23,29,31)$. Therefore, the aim of this study was to evaluate the effect of different solutions and thermal cycling on Vickers hardness of 4 different brands of acrylic resin denture teeth. The study hypothesis was that different storage conditions and thermal cycling had an effect on Vickers hardness of acrylic resin denture teeth.

\section{Materials and Methods}

Four brands of acrylic resin denture teeth are listed in Table 1. For each brand, 15 anterior and 15 posterior acrylic resin denture teeth embedded in autopolymerized acrylic resin. After the polymerization, the occlusal surfaces of the posterior teeth and the vestibule surfaces of anterior were ground flat using 600-, 800-, 1000-, 1200-, and 1500grit silicon carbide paper with running water as the coolant and the surface of teeth were polishing.

Table 1. Acrylic resin denture teeth, identification codes, manufacturers and lot numbers

\begin{tabular}{lccc} 
Material & Code & Manufacturer & Lot Number \\
\hline Acry Rock Ruthinium & $\mathrm{R}$ & S.p.A, Italy & 07105 \\
Acry Lux Ruthinium & $\mathrm{L}$ & S.p.A, Italy & U084 \\
Major Dent & $\mathrm{M}$ & S.p.A, Italy & 7005 \\
Imident Lux & $\mathrm{I}$ & Hannover, Germany & 35305 \\
\hline
\end{tabular}


Thereafter, the hardness of all specimens was obtained using a Vickers diamond indentator. The use of Vickers hardness to determine the microhardness of the acrylic resin denture teeth is in accordance with recent study, which demonstrated that the Vickers indentation is a valid tool for evaluating the hardness, viscoelastic and other responses of rigid polymers (32). Measurements of Vickers hardness number (VHN) were made with a microhardness indentator machine at a $100 \mathrm{~g}$ load for 30 seconds. A load of $100 \mathrm{~g}$ was used so that the indentation could be properly measured (9). The operator of the test machine read the lengths of the diagonals immediately after each indentation, with a minimal (as short as 10 seconds) period of time elapsing between making and reading the indentations. It was assumed that due to the short time interval between making and reading the indentation, the viscoelastic recovery of the diagonals after indentation was minimal (32). The operator measured the diagonals, and the equipment automatically converted these measurements to $\mathrm{VHN}(\mathrm{kg} / \mathrm{mm} 2)$. Three readings were recorded for each specimen and the mean value was calculated.

All specimens were equally divided into 3 groups $(n=5)$ and submitted to different conditions:

1. Condition: Storage in distilled water at $37 \pm 2$

${ }^{\circ} \mathrm{C}$ for 7 days (control);

2. Condition: Storage in artificial saliva at $37 \pm 2$ ${ }^{\circ} \mathrm{C}$ for 30 days;

3. Condition: Storage in disinfectant solution ( $1 \%$ sodium hypochlorite).

The specimens were immersed for $10 \mathrm{~min}$ in the disinfectant solutions and then rinsed with running water for $3 \mathrm{~min}$. The specimens were disinfected twice for 7 days, simulating when dentures were received from the patient and before being returned to the patient. The composition of artificial saliva, which closely resembles natural saliva, is $\mathrm{KCl}(0.4 \mathrm{~g} / \mathrm{l}), \mathrm{NaCl}$ $(0.4 \mathrm{~g} / \mathrm{l}), \mathrm{CaCl}_{2} .2 \mathrm{H}_{2} \mathrm{O}(0.906 \mathrm{~g} / \mathrm{l}), \mathrm{NaH} 2 \mathrm{PO} 4.2 \mathrm{H} 2 \mathrm{O}$ $(0.690 \mathrm{~g} / \mathrm{l}), \mathrm{Na}_{2} \mathrm{~S} .9 \mathrm{H}_{2} \mathrm{O}(0.005 \mathrm{~g} / \mathrm{l})$, Urea $(1 \mathrm{~g} / \mathrm{l})(33)$. All specimens were thermocycled in distilled water between $5{ }^{\circ} \mathrm{C}$ and $55{ }^{\circ} \mathrm{C}$ with 30 -s dwell times for 2500 cycles. After that, the hardness of all specimens was obtained again using a Vickers hardness tester, three readings were recorded for each specimen and the mean value was calculated.

\section{Statistical Analysis}

Analysis of variance (ANOVA) was used to compare results from each acrylic resin denture teeth brand and stored condition. Significant differences between materials were determined using Duncan test. A value of $p<0.05$ was regarded as statistically significant. In addition, t-test was used to statistically evaluation of the differences between the means of the values obtained before and after The data were analyzed with statistical software SPSS 17.0 (SPSS, Inc., Chicago, III).

\section{Results}

Table 2 summarizes the one-way ANOVA results. The VHN showed significant differences among the groups depending on the brand, storage conditions and anterior-posterior property. All interactions between the variables were statistically significant $(p<0.001)$. Storage in different solutions and thermocycled procedure significantly decreased $(p<0.001)$ the Vickers hardness value regardless of the acrylic resin denture teeth brand.

Table 2: The results of analysis of variance (ANOVA)

\begin{tabular}{|c|c|c|c|c|}
\hline Source & df & MS & $\mathbf{F}$ & Sig. \\
\hline Ant-Post & 1 & 201.48 & 355.20 & 0.000 \\
\hline Brand & 3 & 86.59 & 152.66 & 0.000 \\
\hline Conditions & 2 & 23.88 & 42.11 & 0.000 \\
\hline Initial hardness (Covariate) & 1 & 0.84 & 1.47 & 0.226 \\
\hline Ant-Post*Brand & 3 & 4.22 & 7.43 & 0.000 \\
\hline Ant-Post*Conditions & 2 & 11.91 & 20.26 & 0.000 \\
\hline Brand*Conditions & 6 & 11.49 & 20.99 & 0.000 \\
\hline Ant-Post*Brand ${ }^{*}$ Conditions & 6 & 4.52 & 7.96 & 0.000 \\
\hline
\end{tabular}


The minimum, maximum, means and standard deviations of Vickers hardness values with $t$-test are shown in Table 3. Initially, L-post showed the maximum hardness value and I-ant showed the minimum hardness value. Moreover, anterior teeth group showed the little hardness value from posterior teeth group in all brands.
After storage in different solutions and thermocycled procedure, $M$-post showed the maximum hardness value and I-ant showed the minimum hardness value again. There were statistically significant differences between initial and final Vickers hardness values in all groups $(p<0.001)$.

Table 3. Mean and standard deviation of specimens

\begin{tabular}{|c|c|c|c|c|c|c|c|}
\hline \multirow{2}{*}{$\begin{array}{l}\text { Acrylic teeth } \\
\text { brands }\end{array}$} & \multicolumn{3}{|c|}{ Initial Vickers hardness } & \multicolumn{3}{|c|}{ Final Vickers hardness } & \multirow[t]{2}{*}{ t-test } \\
\hline & Minimum & Maximum & Mean \pm SD & Minimum & Maximum & Mean \pm SD & \\
\hline M-ant & 36.0 & 44.0 & $38.7 \pm 1.9$ & 17.1 & 21.4 & $19.6 \pm 1.3$ & $70.2^{* *}$ \\
\hline M-post & 37.5 & 45.5 & $41.0 \pm 2.4$ & 20.7 & 24.0 & $21.9 \pm 1.0$ & $60.9^{* *}$ \\
\hline L-ant & 37.0 & 43.5 & $39.9 \pm 1.9$ & 15.8 & 20.8 & $18.3 \pm 1.1$ & $74.8^{* *}$ \\
\hline L-post & 38.0 & 44.0 & $42.0 \pm 1.6$ & 17.4 & 21.7 & $20.1 \pm 1.0$ & $75.4^{* *}$ \\
\hline R-ant & 35.0 & 41.0 & $37.9 \pm 1.6$ & 15.0 & 19.8 & $17.7 \pm 1.2$ & $64.4^{* *}$ \\
\hline R-post & 36.0 & 43.0 & $39.8 \pm 1.9$ & 18.3 & 20.4 & $20.0 \pm 0.9$ & $53.6^{* *}$ \\
\hline I-ant & 30.5 & 38.0 & $35.0 \pm 2.1$ & 15.3 & 19.0 & $17.4 \pm 1.0$ & $76.3^{* *}$ \\
\hline I-post & 34.0 & 43.5 & $38.4 \pm 2.4$ & 18.0 & 20.7 & $18.8 \pm 0.6$ & $58.7^{* *}$ \\
\hline
\end{tabular}

The hardness mean and standard deviations were calculated for each group in all the 3 conditions. After storage in different solutions and thermocycled procedure, the mean and standard deviation values for each brand and condition are shown in Table. 4. M-post stored in 1. condition showed the maximum hardness value and I-ant stored in 1 . condition showed the minimum hardness value. All posterior teeth group showed higher hardness value than anterior teeth group in all brands.

Table 4. Means and Standard deviations of specimens after different conditions and thermal cycling procedure

\begin{tabular}{ccccccccc} 
Storage & M-ant & M-post & L-ant & L-post & R-ant & R-post & I-ant & I-post \\
conditions & Mean \pm SD & Mean $\pm S D$ & Mean $\pm S D$ & Mean $\pm S D$ & Mean $\pm S D$ & Mean $\pm S D$ & $M e a n \pm S D$ & $M e a n \pm S D$ \\
1.condition & $20.8 \pm 0.5 \mathrm{a}$ & $23.2 \pm 0.5 \mathrm{a}$ & $19.2 \pm 0.2 \mathrm{a}$ & $20.6 \pm 0.6 \mathrm{a}$ & $17.9 \pm 1.0 \mathrm{a}$ & $20.6 \pm 1.1 \mathrm{a}$ & $16.5 \pm 0.8 \mathrm{c}$ & $18.9 \pm 0.8 \mathrm{a}$ \\
2.condition & $18.3 \pm 1.1 \mathrm{c}$ & $21.2 \pm 0.4 \mathrm{~b}$ & $18.0 \pm 1.5 \mathrm{~b}$ & $20.4 \pm 0.5 \mathrm{a}$ & $16.6 \pm 0.7 \mathrm{~b}$ & $20.1 \pm 0.2 \mathrm{a}$ & $18.2 \pm 0.6 \mathrm{a}$ & $19.1 \pm 0.4 \mathrm{a}$ \\
3.condition & $19.7 \pm 0.7 \mathrm{~b}$ & $21.3 \pm 0.3 \mathrm{~b}$ & $17.7 \pm 0.4 \mathrm{~b}$ & $19.2 \pm 1.2 \mathrm{~b}$ & $18.5 \pm 0.8 \mathrm{a}$ & $19.3 \pm 0.7 \mathrm{~b}$ & $17.3 \pm 0.9 \mathrm{~b}$ & $18.4 \pm 0.2 \mathrm{~b}$ \\
\hline
\end{tabular}

\section{Discussion}

In the present study, 4 brands of acrylic resin denture teeth were investigated with respect to the effect of water immersion, artificial saliva, $1 \%$ sodium hypochlorite and thermocycling procedure. The study hypothesis was accepted. This study demonstrated that storage in different solutions and thermal cycling decreased the Vickers hardness of the four different brands of acrylic resin denture teeth evaluated.

The analysis of the surface hardness is performed by using many different methods. These are; Brinell,
Rockwell, Vickers, and Knoop hardness tests. The surface properties of the material to be used is decisive at the choosing the method to be preferred. The hardness tests for many dental materials are defined by the American Dental Association $(5,6)$. While Vickers and Knoop hardness methods are defined as the microhardness tests, Rockwell and Brinell hardness methods are defined as the macro hardness tests. Less than $9.8 \mathrm{~N}$ forces are applied in the microhardness tests and the results of the test, less than $19 \mu \mathrm{m}$ the measurements values are obtained. Many researchers used the Vickers microhardness test method in their 
study of the analysis of the surface hardness of acrylic materials $(4,34)$. As a result, the Vickers microhardness method was used in the present study.

According to Pavarina et al. continuous decrease in hardness was noticed after aging in water (9). It was observed that the surfaces of both acrylic resin denture teeth softened upon immersion in water. It seems that water molecules may interfere with an entanglement of polymer chains and thereby change the physical characteristics of the resultant polymer. According to Anusavice, this permits the relaxation of stresses incurred during polymerization (6).

According to Assunção et al. regarding the storage periods in artificial saliva, the hardness of commercial brands of resin denture teeth decreased with the increase of storage period (24). Some authors observed a Vickers hardness reduction of acrylic resin denture teeth after immersion in water $(9,19)$. The explanation for the decreased hardness is the water's plasticizing effect. Considering that water, as small molecules, may act as a plasticizer following diffusion into the polymer, progressively relaxing of the polymer chains and subsequently reduction of hardness of the acrylic resin denture teeth may occur $(27,31)$. Regarding the storage of denture teeth in saliva, it was observed that saliva acts like water, causing the phenomenon of plasticizing and reduction of denture teeth hardness (24). Gandhi et al. reported that there was no significant difference in microhardness when the artificial teeth were subjected to chemical disinfection (2\% glutaraldehyde, $1 \%$ sodium hypochlorite) (35).

Vickers indentation is a valid tool for evaluating the hardness of rigid polymers. However, very little information is available on the Vickers indentation properties of acrylic denture teeth. This test is based upon the ability of the surface of material to resist penetration by a point under a specified load (6). The indentation produced on the surface of the material from an applied force of a sharp point or an abrasive particle result from the interaction of numerous properties. Among the properties that are related to the hardness of material are elastic modulus and in vitro wear (36).

According to Phoenix, water sorption permits the relaxation of stresses incurred during polymerization (37). According to Campanha et al. the hardness of acrylic resin denture teeth could be affected by microwave sterilization and water immersion (19). To evaluate whether water uptake would influence the effect of microwave sterilization on the hardness of the acrylic resin denture teeth, acted study also included 2 water-immersion specimen groups.

Some authors reported using similar disinfection and testing procedures. Polyzois, Zissis, and Yannikakis observed that storage of a denture base in $2 \%$ alkaline glutaraldehyde for $1 \mathrm{~h}$ resulted in a decrease in microhardness (38). In contrast, Asad et al. observed that storage of a denture base acrylic resin in $2 \%$ alkaline glutaraldehyde, $0,5 \%$ chlorhexidine, and alcohol-based disinfectant solutions for up $24 \mathrm{~h}$ resulted in no significant effect on hardness values (39). However, highly significant change was observed when the resin specimens stored in glutaraldehyde and chlorhexidine for 7 days, were compared with the control specimens. According to the authors, this change could be accounted for by the slow absorption of disinfecting chemicals into the resin that resulted in some structural change in the polymer. Therefore, the absence of any effect of the disinfectant solutions in this study could also be attributed to the exposure time (20 $\mathrm{min}$ ) to the disinfectants. It is important to mention that, in general, the manufacturer's recommended time of immersion disinfection ranges from 10 to 30 $\min$.

\section{Conclusions}

As a result of this study, storage in different solutions and thermal cycling significantly decreased the Vickers hardness of the acrylic resin denture teeth.

The limitation of this in vitro study include that disinfectant solution and storage time is not enough. Different disinfectant solutions will be used. Different type of acrylic resin denture teeth and denture base materials will be evaluated together. Moreover, thermal cycling is an in vitro process used to simulate clinical behavior. The effect of thermal cycling will be evaluated alone and numbers of cycles will be increased.

Peer-review: Externally peer-reviewed.

Author Contributions: Conception - H.Ö.; Design - H.Ö.; Supervision Z.Y.D.; Materials - H.Ö.; Data Collection and/or Processing - H.Ö.., Z.Y.D.; Analysis and/or Interpretation - Z.Y.D.; Literature Review - H.Ö.; Writer H.Ö.; Critical Review - Z.Y.D.

Conflict of Interest: No conflict of interest was declared by the authors.

Financial Disclosure: The authors declared that this study has received no financial support.

\section{References}

1. Zarb GA, Bolender CL. Eckert SE, Jacob RF, Fenton AH, Merickske-stern RM. Prosthodontic treatment for edentulous patients: Complete denture and Implant-supported prosthesis. 12th ed. St. Louis: Mosby; 2004. p. 195-8. 
2. Powers JM, Sakaguchi RL. Craig's Restorative dental materials. 12th ed. Philadelphia: Mosby Elsevier; 2006. p. 544-6.

3. Rhan AO, Heartwell CM. Text book of complete dentures. 5th ed., London, 1993, Lea\&Febiger.

4. Mandikos MN, McGivney GP, Davis E, Bush PJ, Carter JM. A comparison of the wear resistance and hardness of indirect composite resins. J Prosthet Dent 2001;85:386-95. (Crossref)

5. Phillips RW. Science of Dental Materials. 9th ed., Philadelphia, 1991, W.B. Saunders Co.

6. Anusavice KJ. Phillip's Science of Dental Materials, 10th ed., Philadelphia, 1996, W.B. Saunders Co.

7. Wakefield CW. Laboratory contamination of dental prostheses. J Prosthet Dent 1980;44:143-6. (Crossref)

8. Kahn RC, Lancaster MV, Kate W Jr. The microbiologic crosscontamination of dental prostheses. J Prosthet Dent 1982;47:556-9. (Crossref)

9. Pavarina AC, Vergani CE, Machado AL, Giampaolo ET, Teraoka MT. The effect of disinfectant solutions on the hardness of acrylic resin denture teeth. J Oral Rehabil 2003;30:749-52. (Crossref)

10. Brace ML, Plummer KD. Practical denture disinfection. J Prosthet Dent 1993;70:538-40. (Crossref)

11. Lin JJ, Cameron SM, Runyan DA, Craft DW. Disinfection of denture base acrylic resin. J Prosthet Dent 1999;81:202-6. (Crossref)

12. McCabe JF, Smith BH. A method for measuring the wear of restorative materials in vitro. Restorative resins: abrasion vs. mechanical properties. Scand J Dent Res 1980;88:557-68.

13. Blau PJ, Lawn BR, editors. Microindentation techniques in materials science and engineering, ASTM STP 889. Philadelphia: American Society for Testing and Materials; 1986. p. 196-205.

14. Wassell RW, McCabe JF, Walls AW. Subsurface deformation associated with hardness measurements of composites. Dent Mater 1992;8:218-23. (Crossref)

15. McCabe JF, Walls AWG. Applied dental materials, 8th ed., Oxford: Blackwell Science; 1998. p. 4-28.

16. Abe $\mathrm{Y}$, Sato $\mathrm{Y}$, Taji T, Akagawa $\mathrm{Y}$, Lambrechts $\mathrm{P}$, Vanherle $\mathrm{G}$. An in vitro wear study of posterior denture tooth materials on human enamel. J Oral Rehabil 2001;28:407-12. (Crossref)

17. Zeng J, Sato $Y$, Ohkubo C, Hosoi T. In vitro wear resistance of three types of composite resin denture teeth. J Prosthet Dent 2005;94:453-7. (Crossref)

18. Kawano F, Ohguri T, Ichikawa T, Mizuno I, Hasegawa A. Shock absorbability and hardness of commercially available denture teeth. Int J Prosthodont 2002;15:243-7.

19. Campanha NH, Pavarina AC, Vergani CE, Machado AL. Effect of microwave sterilization and water storage on the Vickers hardness of acrylic resin denture teeth. J Prosthet Dent 2005;93:483-7. (Crossref)

20. Kawano F, Ohguri T, Ichikawa T, Matsumoto N. Influence of thermal cycles in water on flexural strength of laboratoryprocessed composite resin. J Oral Rehabil 2001;28:703-7. (Crossref)

21. Kanie T, Arikawa H, Fujii K, Inoue K. Physical and mechanical properties of PMMA resins containing gamma methacryloxypropyltrimethoxysilane. J Oral Rehabil 2004;31:166-71. (Crossref)
22. Yap AU, Mah MK, Lye CP, Loh PL. Influence of dietary simulating solvents on the hardness of provisional restorative materials. Dent Mater 2004;20:370-6. (Crossref)

23. Neppelenbroek KH, Pavarina AC, Vergani CE, Giampaolo ET. Hardness of heat-polymerized acrylic resins after disinfection and long-term water immersion. J Prosthet Dent 2005;93:1716. (Crossref)

24. Assunção WG, Gomes ÉA, Barão VAR, Barbosa DB, Delben JA, Tabata LF. Effect of storage in artificial saliva and thermal cycling on Knoop hardness of resin denture teeth. J Prost Research 2010;54:123-7. (Crossref)

25. Senna PM, Da Silva WJ, Faot F, Del Bel Cury AA. Microwave disinfection: cumulative effect of different power levels on physical properties of denture base resins. J Prosthodont 2011;20:606-12. (Crossref)

26. 2Klironomos T, Katsimpali A, Polyzois G. The effect of microwave disinfection on denture base polymers, liners and teeth: A basic overview. Acta Stomatol Croat 2015;49:242-53. (Crossref)

27. Archadian N, Kawano F, Ohguri T, Ichikawa T, Matsumoto N. Flexural strength of rebased denture polymers. J Oral Rehabil 2000;27:690-6. (Crossref)

28. Gale MS, Darvell BW. Thermal cycling procedures for laboratory testing of dental restorations. J Dent 1999;27:89-99. (Crossref)

29. Chai J, Takahashi Y, Takahashi T, Habu T. Bonding durability of conventional resinous denture teeth and highly crosslinked denture teeth to a pour-type denture base resin. Int $\mathrm{J}$ Prosthodont 2000;13:112-6.

30. Schneider RL, Curtis ER, Clancy JM. Tensile bond strength of acrylic resin denture teeth to a microwave- or heat-processed denture base. J Prosthet Dent 2002;88:145-50. (Crossref)

31. Amin WM. Durability of acrylic tooth bond to polymeric denture base resins. Eur J Prosthodont Restor Dent 2002;10:57-61.

32. Low IM. Effects of load and time on the hardness of a viscoelastic polymer. Mater Res Bull, 1998;33:1753-8. (Crossref)

33. Kinani L, Najıh R, Chtaını A. Corrosion inhibition of titanium in artificial saliva containing fluoride. Leonardo J Sci 2008;12:243-50.

34. Shahdad SA, McCabe JF, Bull S, Rusby S, Wassell RW. Hardness measured with traditional Vickers and Martens hardness methods. Dent Mater 2007;23:1079-85. (Crossref)

35. Gandhi N, Daniel S, Benjamin S, Kurian N, Varghese VS. Evaluation of surface microhardness following chemical and microwave disinfection of commercially available acrylic resin denture teeth. J Clin Diagn Res 2017;11:ZC87-ZC91. (Crossref)

36. Mahoney E, Holt A, Swain M, Kılpatrick N. The hardness and modulus of elasticity of primary molar teeth: anultra-microindentation study. J Dent 2000;28:589-94. (Crossref)

37. Phoenix RD. Denture base resins. In: Anusavice KJ, editor. Phillips' science of dental materials. St Louis: Elsevier; 2003. p. 721-57.

38. Polyzois GL, Zissis AJ, Yannikakis SA. The effect of glutaraldehyde and microwave disinfection on some properties of acrylic denture resin. Int J Prost,1995;8:150-4.

39. Asad T, Watkınson AC, Huggett R. The effect of various disinfectant solutions on the surface hardness of acrylic resin denture base material. Int J Prost, 1993;6:9-12. 